\title{
Nutritional characteristics of conilon coffee genotypes grown in transition altitude with water management in soil
}

\section{Características nutricionais de genótipos de cafeeiro conilon cultivados em altitude de transição com manejos de água no solo}

\author{
Rodrigo Amaro de Salles ${ }^{1 *}$ (D) , Renan Baptista Jordaim ${ }^{2}$ (D) Tafarel Victor Colodetti ${ }^{3}$ (D), \\ Wagner Nunes Rodrigues ${ }^{4}$ (D) J José Francisco Teixeira do Amaral ${ }^{2}$ (D) Marcelo Antonio Tomaz $^{3}$
}

\author{
'Universidade Federal de Viçosa/UFV, Departamento de Fitotecnia, Viçosa, MG, Brasil \\ 2Universidade Federal do Espírito Santo/UFES, Centro de Ciências Agrárias e Engenharias, Alegre, ES, Brasil \\ 3Universidade Federal do Espírito Santo/UFES, Centro de Ciências Agrárias e Engenharias, Núcleo de Pesquisas em Café, Alegre, ES, Brasil \\ ${ }^{4}$ Centro Universitário UNIFACIG, Manhuaçu, MG, Brasil \\ *Corresponding author: rodrigoamarodesalles@gmail.com \\ Received in June 27, 2021 and approved in October 27, 2021
}

\begin{abstract}
The modification of water management in the Conilon coffee (Coffea canephora) crop is a possible strategy to improve nutritional management efficiency and ensure better use of the genotypes for regions of transitional altitude. The objective of this study was to evaluate the nutritional characteristics of 27 genotypes of $C$. canephora and submit them to two water management schemes in soil. The goal was to find evidence of higher leaf contents, exports, and nutrient recycling potential in the productive branches of various genotypes. The experiment was carried out in a randomized block design with three replications in a split-plot scheme. The treatment consisted of 27 genotypes of C. canephora and two water management schemes in soil ("Irrigated" and "Rainfed"). Nutritional content in leaves, exported by fruits, and pruned (leaves and stem of plagiotropic branches) recyclable contents were evaluated for nitrogen, phosphorus, potassium, calcium, and magnesium. Variations were observed among genotypes for all the parameters evaluated in both water management in soil. However, significant homogeneous groups were formed among the genotypes in the irrigated management. Furthermore, the genotypes showed distinct nutritional characteristics in response to water management in the soil. Genotypes 108 and 302 had higher nutritional content and were exported by fruits, regardless of soil water management.
\end{abstract}

Index terms: Coffea canephora; mineral nutrition; nutrient cycling; soil moisture.

\begin{abstract}
RESUMO
A modificação do manejo hídrico na cultura do café Conilon (Coffea canephora) pode ser uma estratégia para melhorar a eficiência do manejo nutricional e garantir um melhor aproveitamento por parte dos genótipos para região de altitude de transição. 0 objetivo do estudo foi avaliar as características nutricionais de 27 genótipos de C. canephora, submetidos a dois manejos de água no solo, visando identificar genótipos que apresentam evidências de maiores teores foliares, exportações e potencial de reciclagem de nutrientes em seus ramos produtivos. O experimento foi conduzido em esquema de parcelas subdividida, em delineamento de blocos casualizados, com três repetições. Os tratamentos consistiram nos 27 genótipos de $C$. canephora e dois manejos de água no solo ("Irrigado" e "Suprido apenas pela chuva"). Foram avaliados os teores nutricionais foliares, os conteúdos nutricionais exportados pelos frutos e os conteúdos nutricionais potencialmente recicláveis após a poda (folhas e caule dos ramos plagiotrópicos), dos macronutrientes: nitrogênio, fósforo, potássio, cálcio e magnésio. Houve diferenciação entre os genótipos para todas as características avaliadas em ambos os manejos de água no solo. Porém, houve formação de um maior número de grupos homogêneos entre os genótipos no manejo irrigado. Os genótipos apresentaram distinção nas características nutricionais em resposta aos manejos de água no solo. Os genótipos 108 e 302 acumularam maiores conteúdos nutricionais exportado pelos frutos, independentemente do manejo de água no solo.
\end{abstract}

Termos para indexação: Coffea canephora; nutrição mineral; ciclagem de nutrientes; umidade do solo. 


\section{INTRODUCTION}

Brazil is the largest coffee producer in the world. It accounts for approximately $35 \%$ of the world's coffee production (International Coffee Organization - ICO, 2021). In 2021, the Brazilian coffee crop was estimated at 2.93 million tons, out of which Coffea canephora Pierre ex Froehner represented 0.93 million tons. The state of Espírito Santo (ES) is the largest coffee producer of this species in Brazil, contributing about $67 \%$ of the national production (Companhia Nacional de Abastecimento - CONAB, 2021). However, despite high production, there has been a staggering decrease in the cropped area of approximately 150,000 hectares in the last 14 years (CONAB, 2021). This reduction may be further aggravated due to rise in the average temperature caused by climate changes (Bunn et al., 2015).

It has been estimated that the global temperature may increase by about $4.8^{\circ} \mathrm{C}$ by the end of the $21^{\text {st }}$ century (Intergovernmental Panel on Climate Change - IPCC, 2021). As a result, future projections in agroclimatic zoning foresee significant losses of cultivable areas of $C$. canephora in Brazil (Bunn et al., 2015). This will force the coffee species to migrate to regions of higher altitudes classified as unfit or marginal/transitional to cultivation. Therefore, studies on the behavior of different genotypes growing under these specific conditions have peaked in recent years.

C. canephora is an allogamous species with gametophytic self-incompatibility with high genetic variability and reproduces through cross-fertilization. These characteristics facilitate the production of highly heterozygous genotypes (Giles et al., 2018), having adaptive and acclimatizing abilities (Ramalho et al., 2014). In addition, the genetic variability of the species induces differentiated responses in genotype development under different soil water conditions (Bonomo et al., 2017; Ribeiro et al., 2018). Therefore, behavioral studies of $C$. canephora genotypes in specific cultivation conditions provide optimally integrated management systems.

Another significant parameter influenced by genetic variability in the $C$. canephora species is the nutritional status. Scientific evidence has attributed the tolerance to low nutrient availability (Colodetti et al., 2014; Martins et al., 2015), efficient absorption and use of nutrients (Martins et al., 2016), and accumulation of nutritional content in leaves and branches (Oliosi et al., 2020) may significantly be altered by genetic factors.
Water availability also contributes to nutrient uptake due to large volumes of absorbable mineral nutrients in the water (Cramer; Hawkins; Verboom, 2009). Thus, soil moisture management can significantly interfere with the nutritional aspects, such as the accumulation and concentration of nutrients in leaves and fruits of the crop (Covre et al., 2018a; 2018b; Starling et al., 2018). In addition, the adjustment of the internal nutrient content can affect the acclimatization mechanisms (Ramalho et al., 2013), which is directly related to the developmental capacity of the plant under specific environments like higher altitudes.

Therefore, it is essential to collect information on the nutritional responses of improved genotypes of C. canephora under specific cultivation conditions. Hence, the objective of this study was to characterize the nutritional characteristics of 27 genotypes of C. canephora, which were submitted to two water management schemes in the soil at transition altitude. The aim was to identify genotypes with evidence of higher leaf contents, exports, and nutrient recycling capacity in its productive branches.

\section{MATERIAL AND METHODS}

\section{Local characterization}

The experiment was developed in a competitive field in the municipality of Alegre, located in the mountain ranges (Caparaó) of the Espírito Santo State, towards the southeast region of Brazil (20 $52^{\circ} 06^{\prime}$ ' $\left.\mathrm{S}, 41^{\circ} 28^{\prime} 45^{\prime \prime} \mathrm{W}\right)$. The area represents an elevation of $647 \mathrm{~m}$ over sea level and is marginally suitable for crops of $C$. canephora (Taques; Dadalto, 2019).

According to the Köppen-Geiger climate classification, the climate is classified as $C_{w a}$ (humid subtropical) and characterized by rainy summers and dry winters (Peel; Finlayson; Mcmahon, 2007). The soil is classified as a yellow-red latosol (Oxisol) (Empresa Brasileira de Pesquisa Agropecuária EMBRAPA, 2013; United States Department of Agriculture - USDA, 1999), with clayey texture and wavy-rugged relief.

\section{Plantation management}

The plantlets were propagated using asexual reproduction by cutting orthotropic stems of matrix-plants from selected genotypes and by following the cloning and propagation recommendations of C. canephora (Ferrão et al., 2019). 
Once the plantlets developed three to four pairs of fully expanded leaves, they were planted in rows with 3.00 $\times 1.00 \mathrm{~m}$ spacing. After planting, the orthotropic stems were bent to stimulate sprouting and mitigate differential growth patterns among the genotypes of $C$. canephora (Rodrigues et al., 2017). According to the current crop density recommendations, the plants were standardized with three orthotropic stems, resulting in a total population of plants and stems per area. Similarly, other agricultural practices were established following the guidelines customarily required to cultivate $C$. canephora in Brazil (Ferrão et al., 2019).

The plant nutrition was managed and annually monitored using the chemical analysis of the soil. The soil acidity was corrected through liming, and the availability of plant nutrients was facilitated using the same mean, source, and amount, regardless of the treatment. The nutrients were added to the soil monthly, dissolved in the same quantity of water per plant, using a dripping system. However, the amount of water used was only sufficient to transport the nutrients and not supply the plants' hydric demand.

\section{Experimental design}

The experiment used a split-plot scheme, with 27 genotypes of $C$. canephora distributed in the main plots and two water management schemes in the sub-plots. A randomized block design was used with three replications and three plants per experimental plot.

\section{Selected genotypes}

The 27 genotypes of $C$. canephora were composed of three clonal cultivars certified in Brazil by Serviço Nacional de Proteção de Cultivares (SNPC). Nine genotypes were from the cultivar "Diamante ES8112" (SNPC Certification number: 20140103) and were referred to as $101,102,103,104,105,106,107,108$, and 109. In addition, nine genotypes were from the cultivar "Jequitibá ES8122” (SNPC Certification number: 20140104), referred to as 201, 202, 203, 204, 205, 206, 207, 208, and 209. Furthermore, the last nine genotypes were components of the cultivar "Centenária ES8132" (SNPC Certification number: 20140102), referred to as 301,302 , 303, 304, 305, 306, 307, 308, and 309.

All the clonal cultivars were developed and registered by the Instituto Capixaba de Pesquisa, Assistência Técnica e Extensão Rural (INCAPER), and are characterized by high crop yield and significant beverage quality. The genotypes from the cultivar "Diamante
ES8112" present an early-stage ripening cycle. On the other hand, genotypes of "Jequitibá ES8122" have an intermediate ripening cycle and the genotypes from "Centenária ES8132" present a late-ripening cycle.

The characterization of the average yield of the genotypes $\left(\mathrm{kg} \mathrm{ha}^{-1}\right)$ was assessed in the production cycles of 2017/2018 and 2018/2019. The data was presented to help designate the overall behavior of the genotypes in the transitional altitude.

\section{Soil water management}

The two water management schemes consisted of different ways to supply the hydric demand of the plants: irrigated and rainfed systems.

For the irrigated system, soil moisture was monitored using tensiometers (Analogic tensiometer, Soilcontrol TA-76), installed at a depth of $25 \mathrm{~cm}$. The water was distributed using the drip irrigation auto-compensating emissors ( $3.43 \mathrm{~L}$ per hour, spaced by $40 \mathrm{~cm}$ ). Irrigation was performed at a retention potential of at least $70 \%$ of the available water $(34 \mathrm{kPa})$, returning the moisture to field capacity. The physic-hydric analysis of the soil determined the water retention curve. The analysis showed that the soil density was $1.051 \mathrm{~g} \mathrm{dm}^{-3}$, and the moisture was $23.08 \%$ of field capacity and $15.61 \%$ at the wilting point. The system's uniformity and water distribution were evaluated and classified as excellent by the method described by Mantovani et al. (2006).

For the rainfed system, the water input was majorly by natural precipitation which was monitored by an automatic weather station installed nearby the field (Irriplus, E5000).

\section{Evaluated traits}

The 27 genotypes' nutritional characteristics were evaluated at the harvest of 2018-2019. Each plant of the experimental plot collected one plagiotropic branch from the middle part of the canopy. The collected branches were separated into stems, leaves, and fruits. Subsequently, the plant organs were dried separately in a laboratory oven with forced air circulation at $65 \pm 2{ }^{\circ} \mathrm{C}$ (STF SP-102/2000 CIR) until the mass reached a constant weight. A precise electronic scale $(0.0001 \mathrm{~g})$ was used to determine the dry mass of each plant organ.

To obtain a homogeneous powder, the dried tissues were triturated in a Wiley-type mill (Cienlab EC-430, eight blades, $1725 \mathrm{rpm}, 20 \mathrm{mesh}$ ). Then, triplicate samples of this powder were used to determine the concentration of each plant organ's nutrients, viz., $\mathrm{N}, \mathrm{P}, \mathrm{K}, \mathrm{Ca}$, and $\mathrm{Mg}$. 
The $\mathrm{N}$ content was quantified after sulfuric digestion. The contents of $\mathrm{P}, \mathrm{K}, \mathrm{Ca}$, and $\mathrm{Mg}$ were quantified after nitric-perchloric acid digestion, following the current methods for chemical analyses in plants tissues (EMBRAPA, 2000).

The nutritional concentration of leaves, fruits, and leaves + stems with potential for recycling after pruning the plagiotropic branches was analyzed. The dry mass of leaves, stems, and fruits was used to quantify each plant organ's nutritional content (content $=$ multiplication enter the dry mass and the concentration).

\section{Data analyses}

All the data were submitted for analyses of variance. In the presence of significant effects for the various sources, F-test was used to compare soil water management. In addition, the Scott-Knott criterion was used to compare the genotypes, both at a $5 \%$ probability level. Data analyses were performed using "R" software (R Development Core Team, 2021).

\section{RESULTS AND DISCUSSION}

\section{Weather conditions and genotype productivity}

The average annual temperature during the 20182019 production cycle was $20.4{ }^{\circ} \mathrm{C}$, in which the lowest average monthly temperatures were recorded in June and July to be 17.1 and $18.1{ }^{\circ} \mathrm{C}$, respectively (Figure 1). The data suggested clues thermal impediment for the cultivation of $C$. canephora, mainly caused by the effect of altitude, as the ideal annual average temperature would effectively range from 22 to $26^{\circ} \mathrm{C}$ (Taques; Dadalto, 2019).

However, several genotypes of C. canephora displayed acclimatization and tolerance to the environmental conditions of transitional altitude, and some (viz., 104, 106, 108, 201, 203, 205, 302, 303, 304, 306,307 , and 309) showed considerably high productivity from the two harvests $\left(>4800 \mathrm{~kg} \mathrm{ha}^{-1}\right)$ (Figure 2). This adaptive capacity of the genotypes could be based on the observations of Ramalho et al. (2014), which describe that gradual exposure to colder temperatures (as observed infield in the present study) allowed the plants to perform metabolic functions and structural adjustments.

The accumulated precipitation reached $1433 \mathrm{~mm}$, which was above the historical average for the municipality (Figure 1). Therefore, this may have minimized the variation between water management in the soil. However, water inflow in the rainfed management was irregular throughout the observation period, with poor water supply (rain) at crucial junctions for developing coffee fruits. Similar cases were observed in September 2018 (20 mm) and January $2019(20 \mathrm{~mm})$, when the municipal historical average would be approximately $50 \mathrm{~mm}$ and $165 \mathrm{~mm}$, respectively (Instituto Capixaba de Pesquisa, Assistência Técnica e Extensão Rural - INCAPER, 2021).

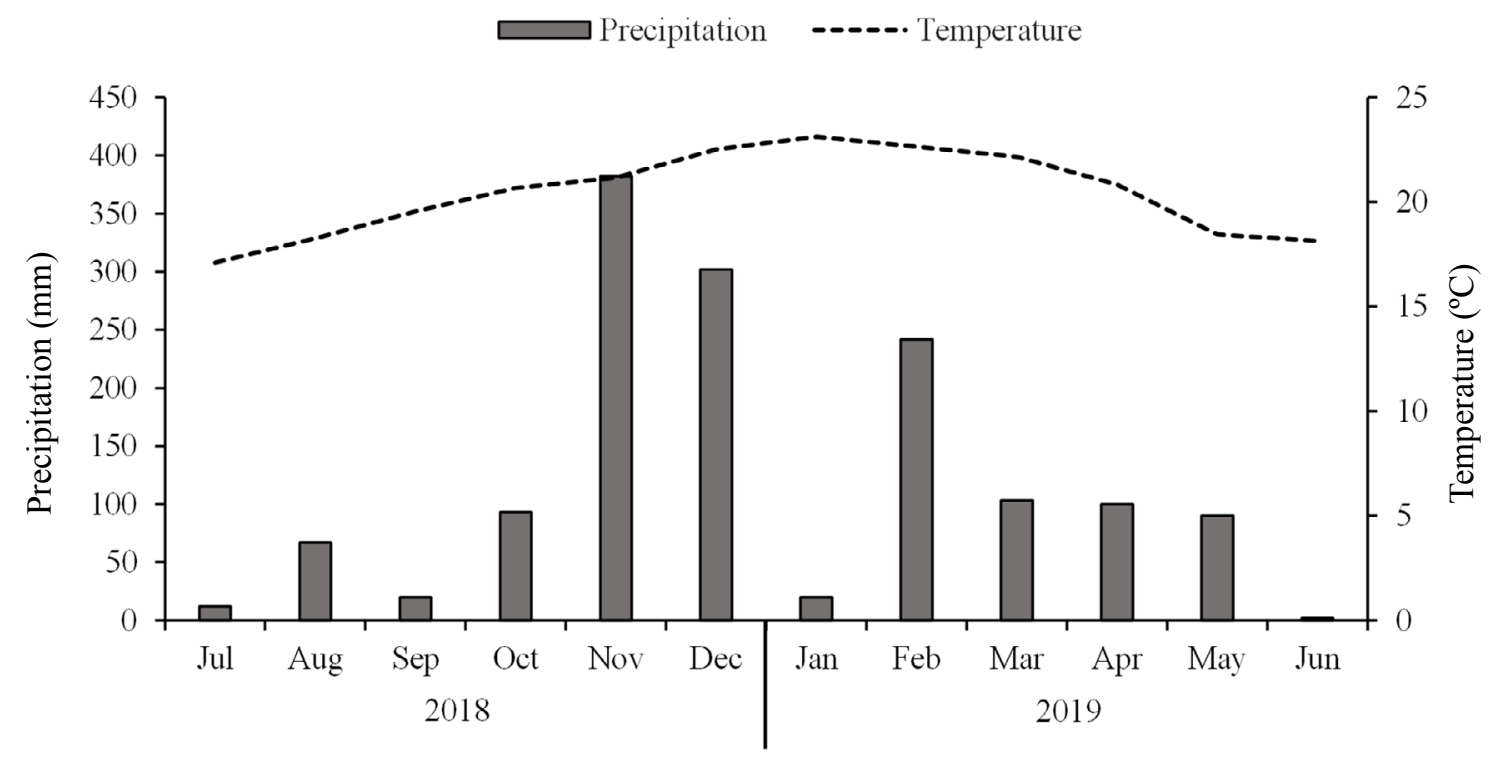

Figure 1: Accumulated precipitation and average monthly temperature recorded from July 2018 to June 2019 (647 m, Lagoa Seca community, Alegre-ES). 


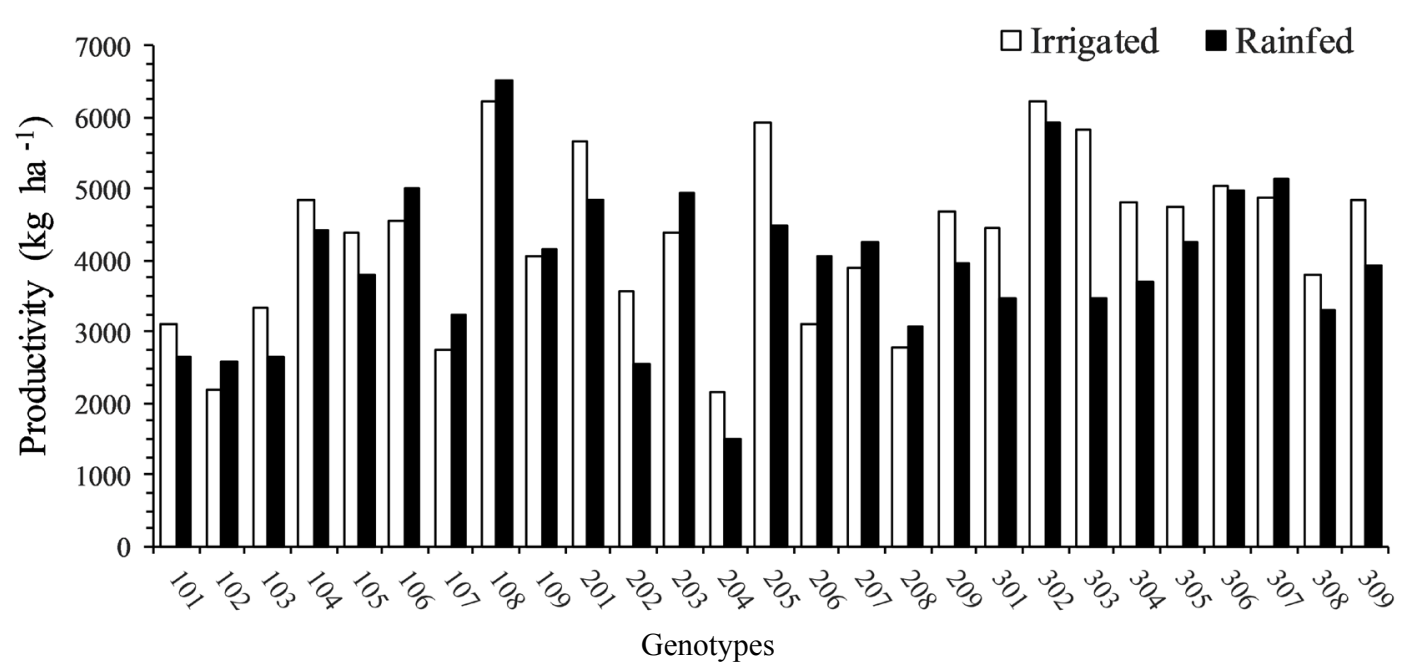

Figure 2: Average productivity ( $\mathrm{kg} \mathrm{ha}^{-1}$ ) of two harvests (2018 and 2019) from 27 genotypes of $C$. canephora, grown at transitional altitude $(647 \mathrm{~m})$ in two water management schemes in the soil (irrigated and rainfed).

\section{Interaction between the factors}

The interaction between the genotypic effects and water management was significant for all the characteristics, except leaf contents of $\mathrm{N}, \mathrm{P}, \mathrm{K}$, and $\mathrm{P}$, which are potentially recyclable (Table 1 ). The isolated effect of each variation source was analyzed in the absence of a significant effect for the interaction.

\section{Nutritional characterization based on macronutrient leaf content}

The soil's isolated effect of the water management factor showed a higher leaf content of $\mathrm{N}$ and $\mathrm{K}$ in irrigated management (Figures 3a and 3c), probably promoted by the higher soil moisture. On the other hand, higher leaf $P$ levels were observed when rainfall supplied the water demand (Figure 3b).

The higher $\mathrm{N}$ content in leaves found in irrigated management contributed to the increased photosynthetic potential in the crop (Bote et al., 2018) as a large part of this nutrient is involved in chlorophyll composition and proteins in carbon fixation and reduction (Taiz et al., 2017).

Higher leaf content of $\mathrm{P}$ was found in managing the water demand supplied by rainfall, attributed to possible root changes observed in $C$. canephora plants under moderate water restriction conditions. Such changes include a longer root length associated with a denser root volume and surface area within the superficial and subsurface layers (Covre et al., 2015; Vicente et al., 2019). This response may contribute to greater root $P$ interceptions, as observed in the present study.
The analysis of the genotype factor showed more significant differentiation between the 27 materials in the leaf $\mathrm{K}$ content with the formation of three genotypic groups (Figure 3c). In contrast, two mean groups were formed for $\mathrm{N}$ and $\mathrm{P}$ (Figures $3 \mathrm{a}$ and $3 \mathrm{~b}$ ). Possibly, some of the genotypes with the highest levels of $\mathrm{P}$ and $\mathrm{K}$ (e.g., 102, 107, 204, and 208) showed average productivity from two relatively low harvests $(<3300$ $\mathrm{kg} \mathrm{ha}^{-1}$ ) (Figure 2), indicating less mobilization of $\mathrm{P}$ and $\mathrm{K}$ towards fruits.

It was also observed that water management factor (irrigated) in soil within the levels of genotypic factor enabled significant gains in the leaf $\mathrm{Ca}$ contents of genotypes 101, 102, 105, 106, 107, 108, 205, 207, 303, and 304, while no significant differences were observed for other genotypes (Figure 4a). Furthermore, the leaf content of $\mathrm{Mg}$ in genotypes 101, 105, 106, 108, 205, 207, and 301 was higher in irrigated management, while genotypes 202, 206, 302, 304, 305, and 307 showed the highest levels in rainfed management. There was no significant difference in water management in soil for other genotypes (Figure $4 \mathrm{~b}$ ).

It was observed that irrigated management promoted a more significant differentiation between the $C$. canephora genotypes for Ca contents (four groups of means) than rainfed management (two groups) (Figure 4a). Similarly, seven groups were formed in the irrigated management between the genotypes and five in the rainfed management for $\mathrm{Mg}$ contents (Figure 4b). 
Table 1: Summary analyses of variance for leaf nutritional content, nutritional content exported by fruits, and potentially recyclable nutritional content of nitrogen $(\mathrm{N})$, phosphorus $(\mathrm{P})$, potassium $(\mathrm{K})$, calcium (Ca), and magnesium (Mg) after pruning the plagiotropic branches (stem + leaves) from 27 genotypes of $C$. canephora grown at transitional altitude and subjected to two soil water management (647 m, Lagoa Seca community, Alegre-ES, 2019 harvest).

\begin{tabular}{|c|c|c|c|c|c|c|}
\hline \multirow{2}{*}{ SV } & \multirow{2}{*}{ DF } & \multicolumn{5}{|c|}{ Mean square of leaf nutritional content } \\
\hline & & $\mathrm{N}\left(\mathrm{g} \mathrm{kg}^{-1}\right)$ & $P\left(g_{k g}^{-1}\right)$ & $\mathrm{K}\left(\mathrm{g} \mathrm{kg}^{-1}\right)$ & $\mathrm{Ca}\left(\mathrm{g} \mathrm{kg}^{-1}\right)$ & $\operatorname{Mg}\left(\mathrm{g} \mathrm{kg}^{-1}\right)$ \\
\hline Genotype (G) & 26 & $15.26^{\star *}$ & $0.17^{\star *}$ & $104.93^{* *}$ & $83.09^{* *}$ & $1.39^{* *}$ \\
\hline Water management (M) & 1 & $118.64^{\star *}$ & $0.24^{*}$ & $1006.61^{* *}$ & $205.57^{\star \star}$ & $0.01^{\mathrm{ns}}$ \\
\hline $\mathrm{G} \times \mathrm{M}$ & 26 & $3.75^{\text {ns }}$ & $0.05^{\text {ns }}$ & $0.08^{\mathrm{ns}}$ & $16.18^{* *}$ & $0.24^{\star *}$ \\
\hline $\mathrm{CV}_{\text {plot }}(\%)$ & & 10.22 & 15.76 & 16.82 & 14.66 & 14.57 \\
\hline $\mathrm{CV}_{\text {subplot }}(\%)$ & & 8.56 & 14.64 & 15.76 & 11.40 & 13.61 \\
\hline Overall mean $\left(\mathrm{g} \mathrm{Kg}^{-1}\right)$ & & 19.49 & 1.30 & 22.51 & 21.22 & 1.45 \\
\hline \multirow{2}{*}{ SV } & \multirow{2}{*}{ DF } & \multicolumn{5}{|c|}{ Mean square of the nutritional content exported by fruits } \\
\hline & & $\mathrm{N}(\mathrm{mg})$ & $\mathrm{P}(\mathrm{mg})$ & $\mathrm{K}(\mathrm{mg})$ & $\mathrm{Ca}(\mathrm{mg})$ & $\mathrm{Mg}(\mathrm{mg})$ \\
\hline Genotype (G) & 26 & $0.28^{* \star}$ & $0.0021^{* *}$ & $0.74^{* \star}$ & $0.04^{\star \star}$ & $0.001^{* *}$ \\
\hline Water management (M) & 1 & $1.24^{* *}$ & $0.0004^{\mathrm{ns}}$ & $5.09^{* \star}$ & $0.12^{* \star}$ & $0.002^{* *}$ \\
\hline $\mathrm{G} \times \mathrm{M}$ & 26 & $0.06^{* *}$ & $0.0005^{* *}$ & $0.15^{\star \star}$ & $0.01^{* *}$ & $0.001^{* *}$ \\
\hline $\mathrm{CV}_{\text {plot }}(\%)$ & & 21.39 & 24.72 & 21.60 & 19.25 & 24.50 \\
\hline $\mathrm{CV}_{\text {subplot }}(\%)$ & & 20.95 & 18.70 & 19.11 & 14.73 & 22.10 \\
\hline Overall mean (mg) & & 754.13 & 78.53 & 1203.95 & 294.86 & 45.38 \\
\hline \multirow{2}{*}{ SV } & \multirow{2}{*}{ DF } & \multicolumn{5}{|c|}{ Mean squares of potentially recyclable nutritional content } \\
\hline & & $\mathrm{N}(\mathrm{mg})$ & $\mathrm{P}(\mathrm{mg})$ & $\mathrm{K}(\mathrm{mg})$ & $\mathrm{Ca}(\mathrm{mg})$ & $\mathrm{Mg}(\mathrm{mg})$ \\
\hline Genotype (G) & 26 & $29374.00^{* \star}$ & $227.20^{\star \star}$ & $36929.00^{* *}$ & $112902.00^{* *}$ & $778.88^{* *}$ \\
\hline Water management $(\mathrm{M})$ & 1 & $3832.00^{\star *}$ & $73.15^{\text {ns }}$ & $1409142.00^{* *}$ & $239524.00^{\star *}$ & $607.03^{* *}$ \\
\hline $\mathrm{G} \times \mathrm{M}$ & 26 & $7462.00^{*}$ & $49.35^{\text {ns }}$ & $20321.00^{* *}$ & $30921.00^{* *}$ & $178.15^{\star *}$ \\
\hline $\mathrm{CV}_{\text {plot }}(\%)$ & & 12.35 & 15.38 & 14.76 & 14.83 & 14.19 \\
\hline $\mathrm{CV}_{\text {subplot }}(\%)$ & & 12.44 & 15.56 & 14.91 & 14.91 & 18.16 \\
\hline Overall mean (mg) & & 501.10 & 37.39 & 549.69 & 607.86 & 42.21 \\
\hline
\end{tabular}

** and * significant at $1 \%$ and $5 \%$ of probability, respectively; ${ }^{\text {ns }}$ non-significant; DF: degree of freedom; SV: source of variation; CV: coefficient of variation.

The nutritional levels in leaves found in the current study (Figures 3 and 4) could be compared with the nutritional sufficiency in the pre-anthesis (pre-flowering) period, adjusted for the high-yielding crops of $C$. canephora in the state of Espírito Santo: $\mathrm{N}\left(24.3-34.2 \mathrm{~g} \mathrm{~kg}^{-1}\right), \mathrm{P}\left(1.11-1.76 \mathrm{~g} \mathrm{~kg}^{-1}\right), \mathrm{K}(10.6-$ $\left.17.5 \mathrm{~g} \mathrm{~kg}^{-1}\right), \mathrm{Ca}\left(16.9-31.6 \mathrm{~g} \mathrm{~kg}^{-1}\right)$ and $\mathrm{Mg}(2.7-5.4$ $\mathrm{g} \mathrm{kg}^{-1}$ ) (Partelli et al., 2016), except the nutrients $\mathrm{N}$ and $\mathrm{Mg}$. However, leaf content obtained in the study referred to the phenological stage of fruit maturation, indicating that the nutrition in plants was well within acceptable ranges.

\section{Macronutrient export by fruits of the plagiotropic branch}

There was significant export of N, P, and K by fruits in the plagiotropic branches of $C$. canephora genotypes when subjected to irrigated management (Figure 5) due to a drier mass of fruits in those branches. The higher exports of N, P and K, correlate with higher genotypic yields in irrigated management due to enhanced productivity of most genotypes (average of two harvests) (Figure 2).

The irrigated management promoted differentiation between the genotypes for nutrient export, except for the $\mathrm{P}$ content. It was observed that the formation of four groups 

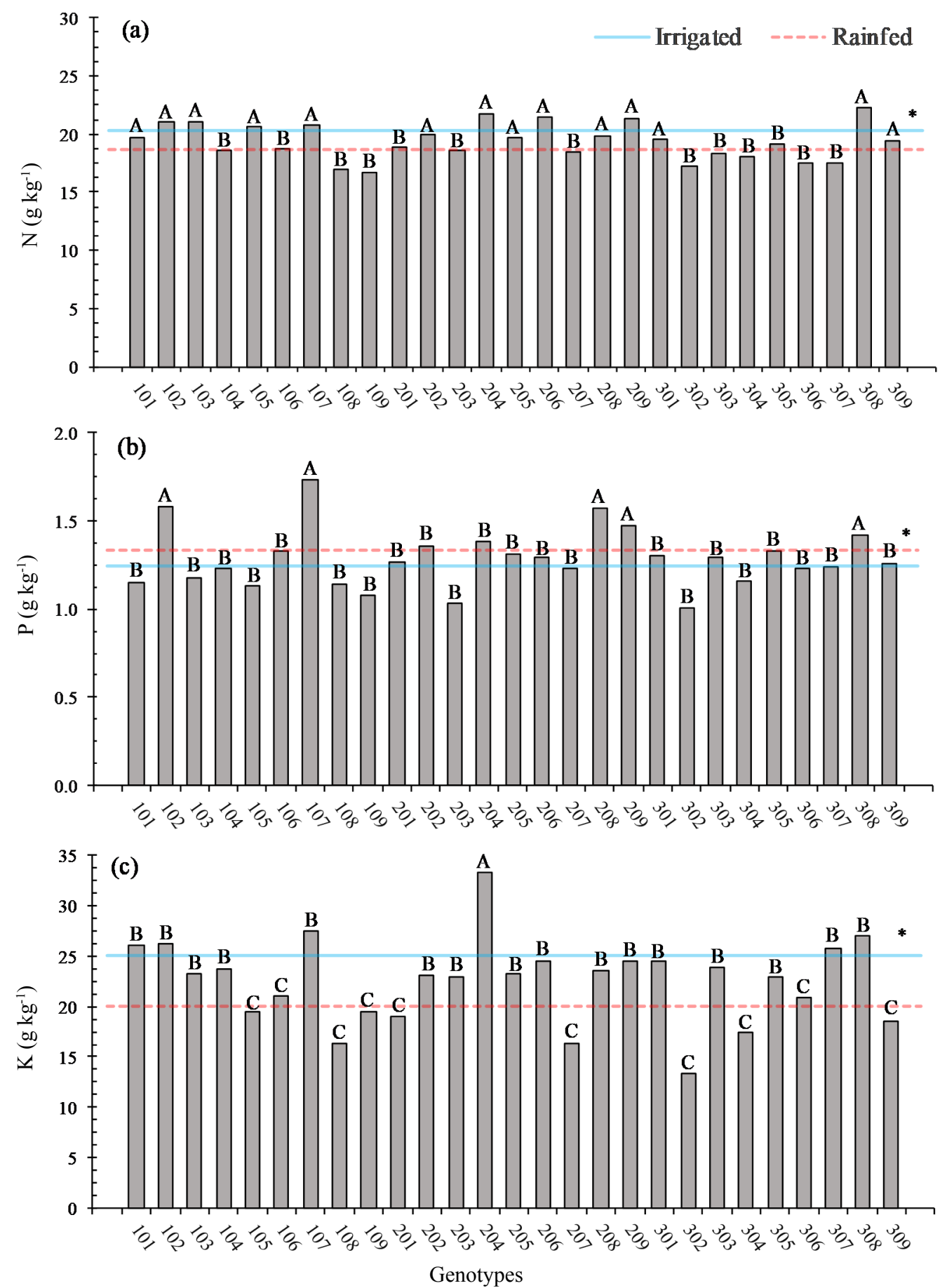

Figure 3: Leaf nutritional content of $\mathrm{N}(\mathrm{a}), \mathrm{P}(\mathrm{b})$, and $\mathrm{K}$ (c) in 27 genotypes of $\mathrm{C}$. canephora under two water management schemes in the soil (irrigated and rainfed), grown at transitional altitude $(647 \mathrm{~m})$. Means followed by the same capital letter in comparing genotypes do not differ by the Scott-Knott criterion $(p \leq 0.05)$. * Significant difference between water management in the soil was determined by the F-test $(p \leq 0.05)$. 
of means between the genotypes for $\mathrm{N}$ and $\mathrm{K}$ content was exported in irrigated management. In comparison, three groups were observed in rainfed management (Figures 5a and $5 \mathrm{c}$ ). These nutrients are essential for the organoleptic characteristics of coffee beans and caffeine content, total phenols, total sugars, and acidity (Clemente et al., 2015; Bote; Vos, 2017).

The export of $\mathrm{Ca}$ showed the predominance of higher contents among the genotypes in rainfed management (e.g., 106, 109, 201, 203, 205, 206, 207, 208, 302, 305, and 308). In contrast, only the genotypes 209 and 309 depicted higher averages in irrigated management (Figure 6a). As for the export of $\mathrm{Mg}$, all the observed significant differences occurred with the highest means in irrigated management (e.g., 102, 104, 106, and 209) (Figure 6b).
More significant differentiation was found between the genotypes in irrigated management for $\mathrm{Ca}$ and $\mathrm{Mg}$ exports. Five and four groups of means were observed between the genotypes for $\mathrm{Ca}$ and $\mathrm{Mg}$ exports, respectively, in irrigated management. Similarly, four and three groups were observed in rainfed management for $\mathrm{Ca}$ and $\mathrm{Mg}$ exports, respectively (Figures 6a and 6b).

Genotype 108 was only included in the group with the highest means to export all nutrients, regardless of water management in the soil (Figures 5 and 6). This function demonstrated its ability to extract and export nutrients, which was related to the expressive and productive capacity of the genotype (Figure 2). Therefore, adjusting the nutritional management in some genotypes is required to restrict the depletion of soil fertility.

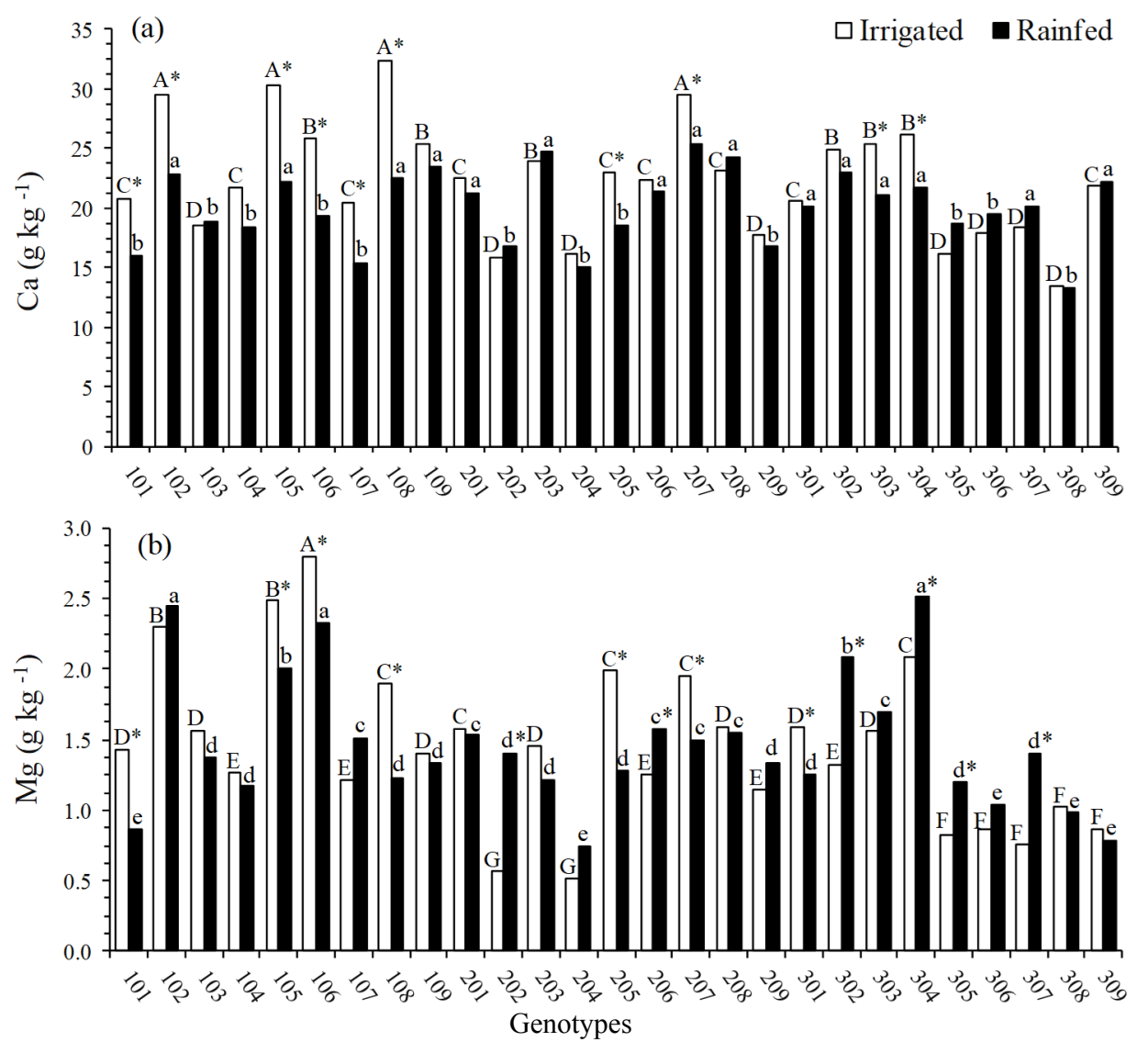

Figure 4: Leaf nutritional content of $\mathrm{Ca}(\mathrm{a})$ and $\mathrm{Mg}(\mathrm{b})$ in 27 genotypes of $C$. canephora grown at transitional altitude $(647 \mathrm{~m})$ under two water management schemes in soil (irrigated and rainfed). Means followed by the same upper-case letter in comparing the genotypes in the irrigated management or the same lower-case letter in comparing the genotypes in the rainfed management did not differ by the Scott-Knott criterion $(p \leq 0.05)$. *Significant difference between water management in soil for the same genotype was analyzed by the F-test ( $p \leq 0.05)$. 

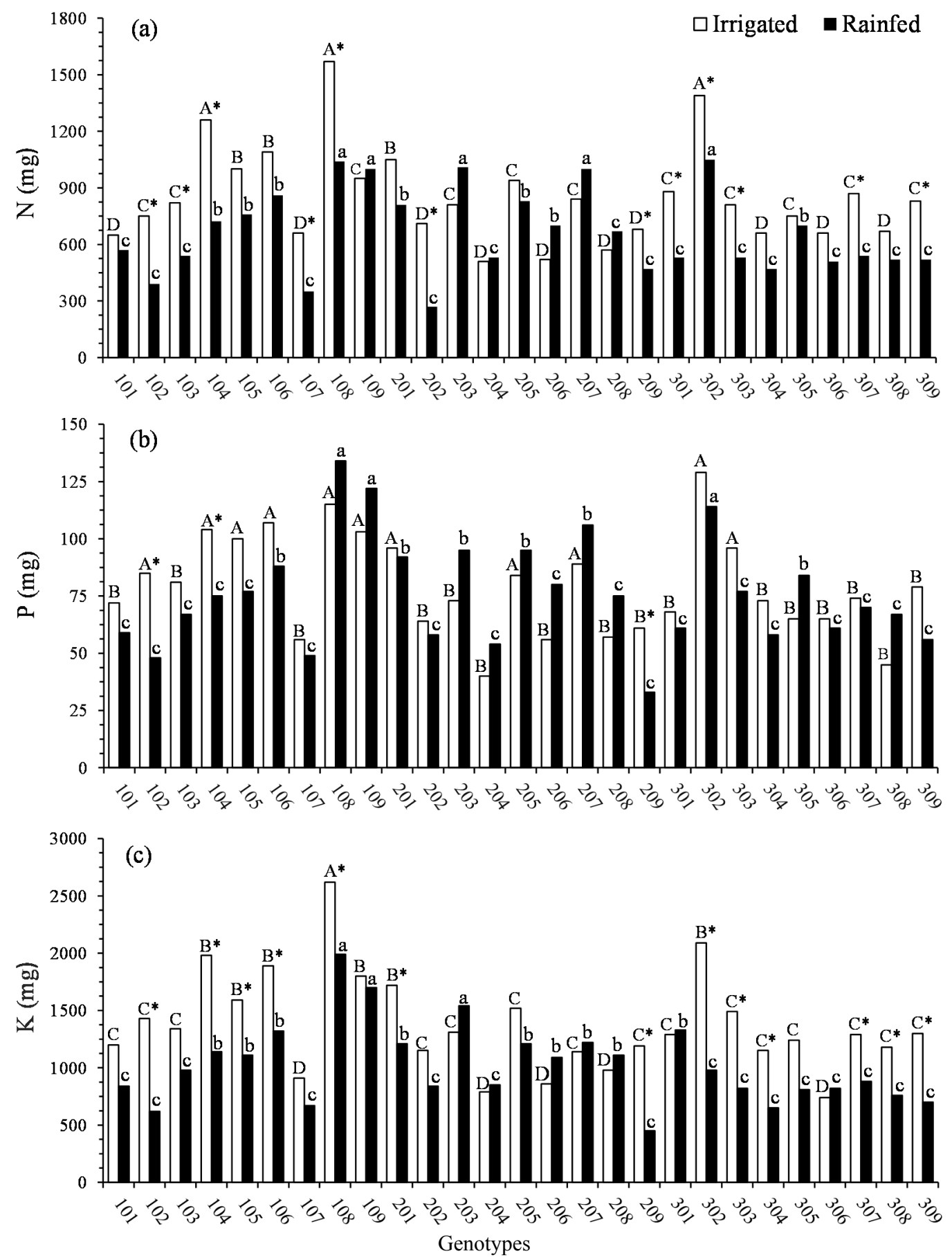

Figure 5: The nutritional content of $\mathrm{N}(\mathrm{a}), \mathrm{P}(\mathrm{b})$, and $\mathrm{K}(\mathrm{c})$ exported by the fruits of 27 genotypes of $\mathrm{C}$. canephora grown at transitional altitude $(647 \mathrm{~m})$ under two water management schemes in soil (irrigated and rainfed). Means followed by the same upper-case letter in comparing genotypes in the irrigated management or the same lower-case letter in comparing genotypes in rainfed management do not differ by the Scott-Knott criterion at 5\% $(p \leq 0.05)$. * Significant difference between water management in the soil for the same genotype was evaluated by the F-test $(p \leq 0.05)$. 

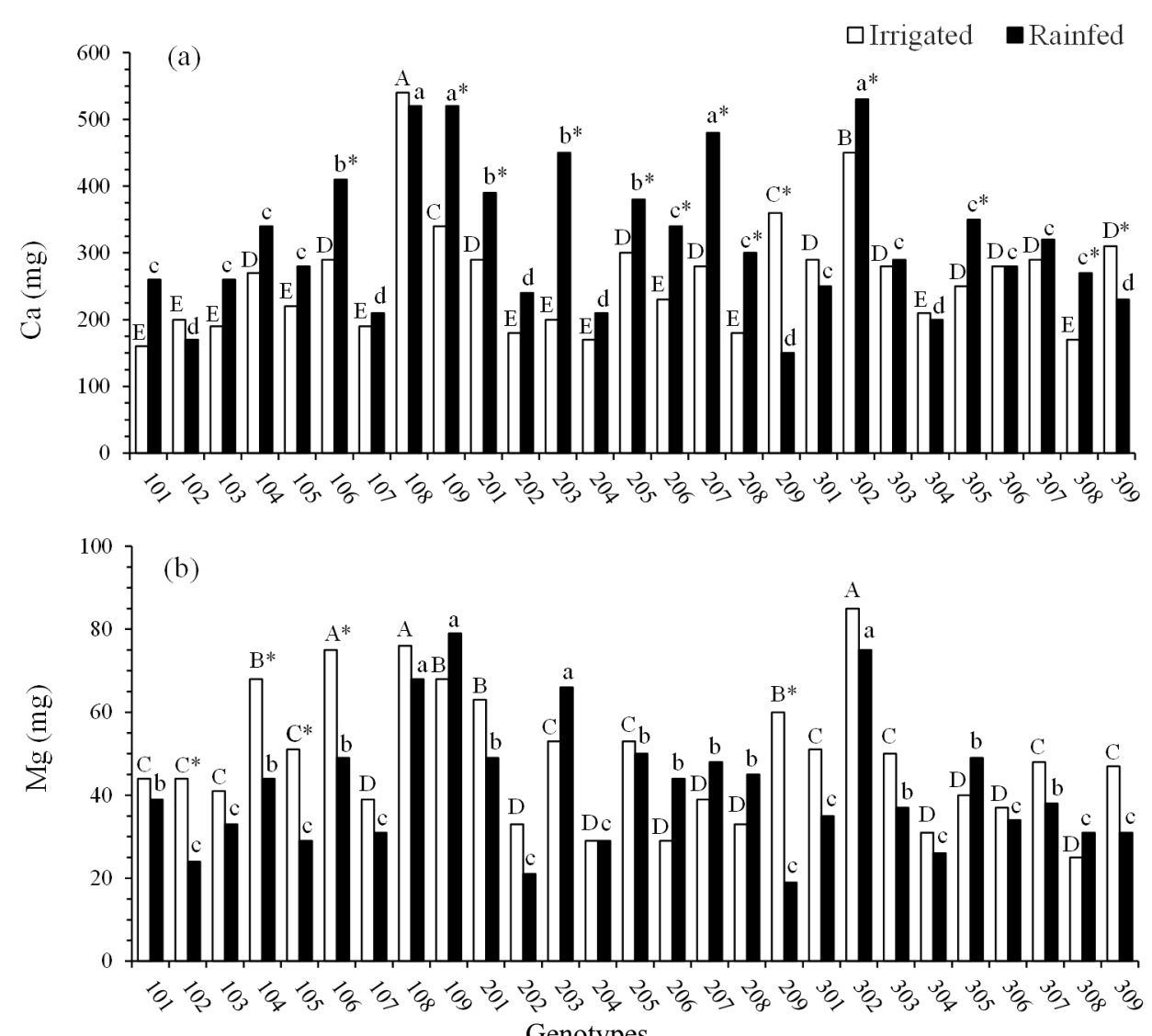

Genotypes

Figure 6: The nutritional content of $\mathrm{Ca}(\mathrm{a})$ and $\mathrm{Mg}(\mathrm{b})$ exported by the fruits of 27 genotypes of $\mathrm{C}$. canephora grown at transitional altitude $(647 \mathrm{~m})$ under two water management schemes in the soil (irrigated and rainfed). Means followed by the same upper-case letter in comparing the genotypes in the irrigated management or the same lowercase letter in comparing the genotypes in the rainfed management do not differ by the Scott-Knott criterion ( $\leq \leq 0.05)$. *Significant difference between water management in the soil for the same genotype was evaluated by the F-test $(p \leq 0.05)$.

Mineral elements in plants like $\mathrm{N}, \mathrm{P}, \mathrm{K}$, and $\mathrm{Mg}$ have high mobility (Marschner, 2011) and reach the fruits through the phloem. However, the transport in the phloem can be severely compromised due to the increased viscosity of the sap during low water availability (Sevanto, 2014), which explains the predominance of higher export averages of these nutrients in irrigated management.

These results indicated that the nutritional needs of the genotypes of $C$. canephora were modulated by the growing conditions, the management of water in the soil, and each genotype's intrinsic productive capacity.

\section{Potentially-recyclable macronutrient content after pruning of plagiotropic branches}

After fruit harvest in plantations of $C$. canephora, pruning practices have to be carried out. In the programmed pruning system (how the plants of the experiment were managed), until the fourth or fifth harvest, shoots and plagiotropic branches exhausted by the harvest were removed (Verdin Filho et al., 2014). Thus, pruning leads to an annual deposition of plagiotropic branches (leaves and stems) on the ground, acting as a source of organic materials and nutrient cycling.

All the genotypes that showed significant differences between soil water management of $\mathrm{N}$ and $\mathrm{K}$ contents with potential for recycling after pruning the plagiotropic branches showed higher content in irrigated management (Figures $7 \mathrm{a}$ and $7 \mathrm{c}$ ). However, no significant difference was observed between water management (Figure 7b).

Three groups of means were formed in the potentially recyclable $\mathrm{N}$ and $\mathrm{K}$ contents in irrigated 

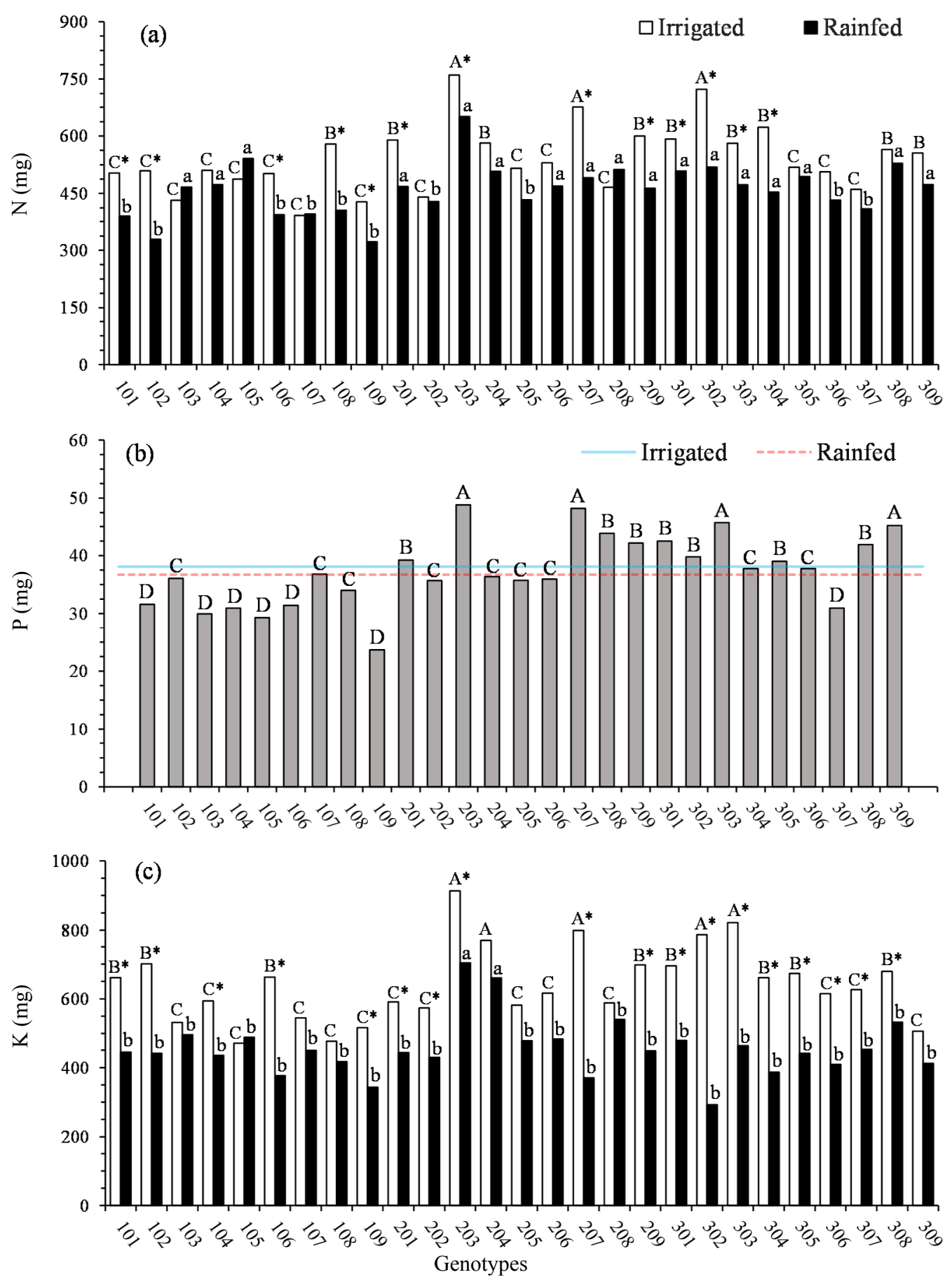

Figure 7: The nutritional content of potentially recyclable $N(a), P(b)$, and $K(c)$ after pruning of plagiotropic branches (stem + leaves) from 27 genotypes of $C$. canephora grown at transitional altitude $(647 \mathrm{~m})$ under two water management schemes in the soil (irrigated and rainfed). Both (a) and (c) means followed by the same upper-case letter in comparing the genotypes in irrigated management or by the same lower-case letter in comparing the genotypes in rainfed management, do not differ by the Scott-Knott criterion ( $p \leq 0.05)$. (b) Means followed by the same upper-case letter in comparing the genotypes do not differ by the Scott-Knott criterion $(p \leq 0.05)$. * Significant difference between water management in the soil was determined by the F-test $(p \leq 0.05)$. 
management, and two groups of means were formed in rainfed management (Figures $7 \mathrm{a}$ and $7 \mathrm{c}$ ). Four groups of means were formed among the genotypes (Figure $7 b)$. It is worth mentioning that genotypes 203,207 , and 302 (recyclable $\mathrm{N}$ content) and genotypes 203 and 204 (recyclable K content) were incorporated in the group of highest averages regardless of soil water management (Figures 7a and 7c).

Few genotypes showed a significant difference between water management in soil for $\mathrm{Ca}$ and $\mathrm{Mg}$ content with the potential for recycling after pruning. However, all of them (genotypes 102, 106, 108, 109, 207, 209, 302, 303, and 304 for Ca; genotypes 101, 102, 106, 108, 205,
207, and 304 for $\mathrm{Mg}$ ) showed higher mean content of these nutrients in irrigated management (Figures 8a and 8b).

Regarding the content of potentially recyclable $\mathrm{Ca}$, three mean groups were formed in irrigated management and four groups in rainfed management (Figure 8a). As for the Mg content, the genotypes formed four mean groups in both water management schemes in soil (Figure 8b).

Nutrient cycling is necessary for both natural and agricultural systems. It helps plants recover and reuse mineral nutrients present in the dead plant or animal residues through microorganism-mediated processes (Hopkins; Dungait, 2010). The programmed pruning
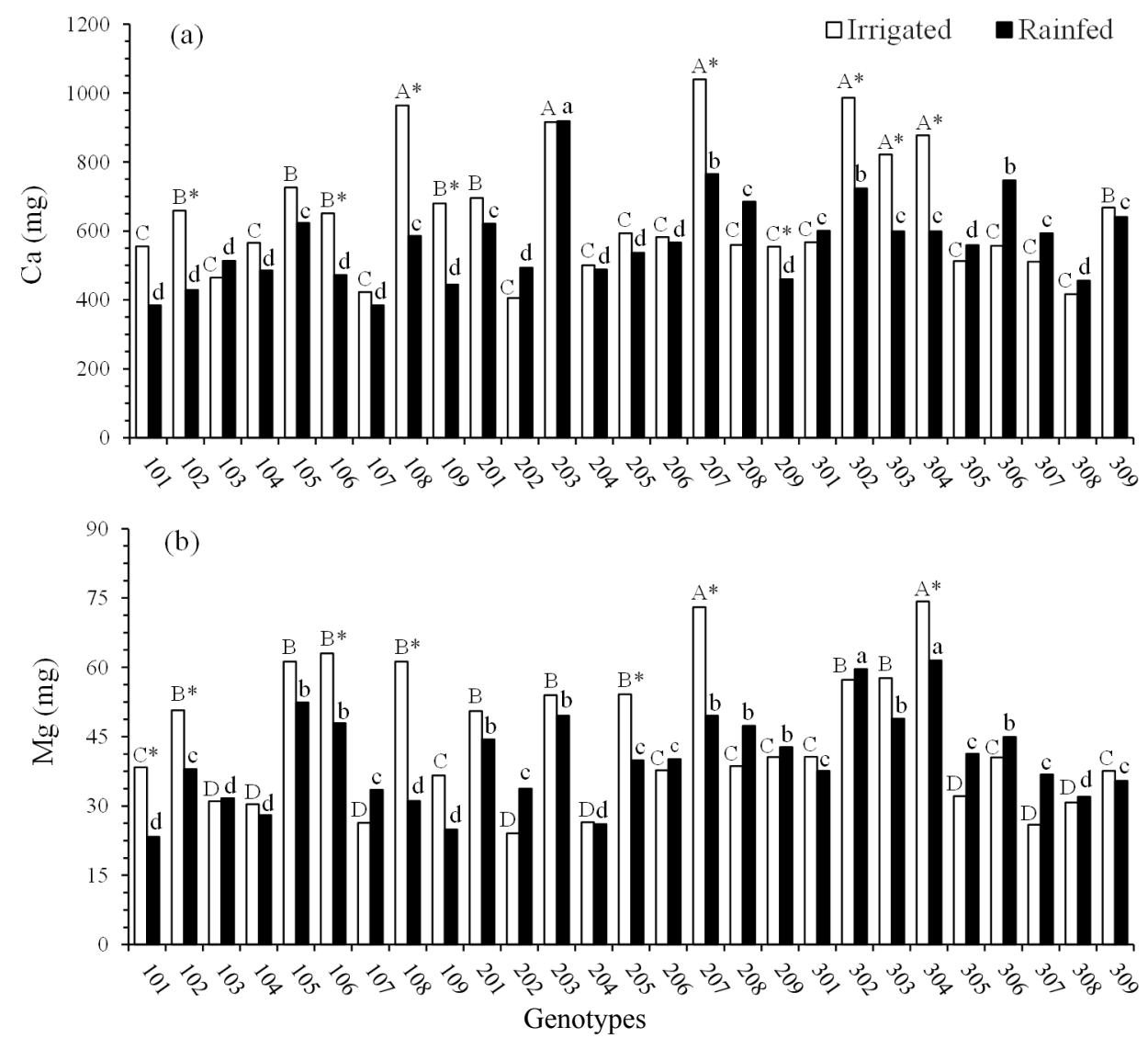

Figure 8: The nutritional content of potentially recyclable $\mathrm{Ca}(\mathrm{a})$ and $\mathrm{Mg}(\mathrm{b})$ after pruning of plagiotropic branch (stem + leaves) from 27 genotypes of $C$. canephora grown at transitional altitude $(647 \mathrm{~m})$ under two water management in the soil (irrigated and rainfed). Means followed by the same upper-case letter in comparing the genotypes in the irrigated management or the lower-case letter in comparing the genotypes in the rainfed management do not differ by the Scott-Knott criterion $(p \leq 0.05)$. * Significant difference between soil water management for the same genotype determined by the F-test $(p \leq 0.05)$. 
cycle of $C$. canephora is an agricultural technique that generates a large volume of plant residues, leaves, and plagiotropic branches (Fonseca et al., 2019), with the availability of a considerable amount of recyclable nutrients. Therefore, genotypes in irrigated management also showed more significant potential for deposition of organic materials and nutrient cycling after pruning, indicating higher efficiencies of the productive system of C. canephora at transitional altitude.

In addition, factors such as moisture and temperature may influence microbial activity and, subsequently, nutrient cycling (Tully; Ryals, 2017). Therefore, the transitional altitude combined with water management in the soil may impact nutrient cycling dynamics in a $C$. canephora plantation.

\section{CONCLUSIONS}

There is a difference among the various genotypes of $C$. canephora grown at transitioning altitude. Changes were observed in leaf contents, nutritional contents exported by fruits, and recyclable nutritional contents of $\mathrm{N}, \mathrm{P}, \mathrm{K}, \mathrm{Ca}$, and $\mathrm{Mg}$ after pruning (leaves and stems of the plagiotropic branches) in both soil water management. However, there is a significant difference between genotypes in irrigated management. Water management in soil influences the nutritional behavior of $C$. canephora genotypes grown at transition altitude. Also, irrigated management promotes higher export of $\mathrm{N}, \mathrm{P}, \mathrm{K}$, and $\mathrm{Mg}$ by fruits, the nutritional content of potentially recyclable $\mathrm{N}, \mathrm{K}, \mathrm{Ca}$, and $\mathrm{Mg}$ after pruning, and $\mathrm{N}, \mathrm{K}$, and $\mathrm{Ca}$ of the leaves. The assessed genotypes were distinct regarding the nutritional aspects in response to soil water management. Genotypes 102, 105 , and 208 accumulated higher macronutrients in leaves. Genotypes 108 and 302 stood out for better export of macronutrients by fruits. After pruning the plagiotropic branches, genotypes 203, 207, 302, and 303 accumulated significantly higher recyclable macronutrients. The different responses among genotypes indicated the existence of variability. Therefore, future studies and breeding programs could explore the nutritional characteristics of C. canephora for plantations in regions of transitional altitude and even consider specific systems for water management, such as irrigated and rainfed crops.

\section{AUTHOR CONTRIBUTION}

Data collection, Data analysis and interpretation, and Writing and editing: Salles, R. A.; Data collection: Jordaim, R. B; Conceptual idea, Methodology design: Colodetti, T. V.; Rodrigues, W. N.; Amaral, J. F. T.; Tomaz, M. A.

\section{ACKNOWLEDGMENTS}

The authors would like to thank José Augusto Demartini Landi and his family for providing access to the plantation, and to the Centro de Ciências Agrárias e Engenharias da Universidade Federal do Espírito Santo (CCAE/UFES) for providing access to the necessary facilities and laboratories. The first and second authors' master's scholarships were funded by the Fundação de Amparo à Pesquisa e Inovação (FAPES). The third author was provided with the regional scientific development grant (process 300971/2021-4) by the Conselho Nacional de Desenvolvimento Científico e Tecnológico (CNPq) and FAPES assistance under the project FAPES 535/2020. The sixth author received financial support from the Secretaria de Estado da Agricultura, Abastecimento, Aquicultura e Pesca (SEAG) and FAPES under the PPE/AGRO project 76440800/16.

\section{REFERENCES}

BONOMO, D. Z. et al. Performance of conilon coffee genotypes under different adjusted crop coefficients. Irriga, 22(1):236248, 2017.

BOTE, A. D. et al. Analysis of coffee (Coffea arabica L.) performance in relation to radiation level and rate of nitrogen supply II. Uptake and distribution of nitrogen, leaf photosynthesis and first bean yields. European Journal of Agronomy, 92:107-114, 2018.

BOTE, A. D.; VOS, J. Tree management and environmental conditions affect coffee (Coffea arabica L.) bean quality. NJAS-Wageningen Journal of Life Sciences, 83:39-46, 2017.

BUNN, C. et al. A bitter cup: Climate change profile of global production of Arabica and Robusta coffee. Climatic Change, 129(1):89-101, 2015.

CLEMENTE, J. M. et al. Effects of nitrogen and potassium on the chemical composition of coffee beans and on beverage quality. Acta Scientiarum. Agronomy, 37(3):297305, 2015.

COLODETTI, T. V. et al. Differential tolerance between genotypes of conilon coffee ('Coffea canephora') to low availability of nitrogen in the soil. Australian Journal of Crop Science, 8(12):1648-1657, 2014.

COMPANHIA NACIONAL DE ABASTECIMENTO - CONAB. Acompanhamento da safra brasileira de café. Brasília: CONAB, 8(2), 2021. 63p. Available in: <https://www.conab. gov.br>. Access in: October 27, 2021. 
COVRE, A. M. et al. Impacts of water availability on macronutrients in fruit and leaves of Conilon coffee. Pesquisa Agropecuária Brasileira, 53(9):1025-1037, 2018a.

COVRE, A. M. et al. Micronutrients in the fruits and leaves of irrigated and non-irrigated coffee plants. Journal of Plant Nutrition, 41(9):1119-1129, 2018b.

COVRE, A. M. et al. Distribuição do sistema radicular de cafeeiro conilon irrigado e não irrigado. Pesquisa Agropecuária Brasileira, 50(11):1006-1016, 2015.

CRAMER, M. D.; HAWKINS, H. J.; VERBOOM, G. A. The importance of nutritional regulation of plant water flux. Oecologia, 161(1):15-24, 2009.

EMPRESA BRASILEIRA DE PESQUISA AGROPECUÁRIA EMBRAPA. Métodos de análise de tecidos vegetais utilizados na Embrapa. Rio de Janeiro: Embrapa Solos, 2000. 41p. (Embrapa Solos. Circular Técnica; 6).

EMPRESA BRASILEIRA DE PESQUISA AGROPECUÁRIA EMBRAPA. Sistema brasileiro de classificação de Solos. 3.ed. Rio de Janeiro: Embrapa Solos, 2013. 353p.

FERRÃO, R. G. et al. Conilon coffee. 3.ed. Vitória: Incaper, 2019. 973p.

FONSECA, A. F. A. et al. Management of Conilon coffee cultivation: planting, spacing, pruning and pinching. In: FERRÃO, R. G. et al. Conilon coffee. 3.ed. Vitória: Incaper, p. 327-360, 2019.

GILES, J. A. D. et al. Genetic diversity of promising 'conilon'coffee clones based on morpho-agronomic variables. Anais da Academia Brasileira de Ciências, 90(2):2437-2446, 2018.

HOPKINS, D. W.; DUNGAIT, J. A. Soil microbiology and nutrient cycling. In: DIXON, G. R.; EMMA, L. Soil microbiology and sustainable crop production. Dordrecht: Springer, p.5980, 2010.

INTERNATIONAL COFFEE ORGANIZATION - ICO. Total production by all exporting countries. London: ICO, 2021. Available in: <https://www.ico.org>. Access in: October 27, 2021.

INSTITUTO CAPIXABA DE PESQUISA, ASSISTÊNCIA TÉCNICA E EXTENSÃO RURAL - INCAPER. Gráficos da série histórica. Alegre/ES. 2021. Available in: <https://meteorologia. incaper.es.gov.br/graficos-da-serie-historica-alegre>. Access in: October 27, 2021.

INTERGOVERNMENTAL PANEL ON CLIMATE CHANGE IPCC. Climate change 2021: The physical science basis. Cambridge: Cambridge University Press, 2021. Available in: <https://www.ipcc.ch/>. Access in: October 27, 2021.
MANTOVANI, E. C.; BERNARDO, S.; PALARETTI, L. F. Irrigação: princípios e métodos. Viçosa, MG: UFV, 2006. 318p.

MARSCHNER, H. Mineral nutrition of higher plants. New York: Academic Press, 2011. 651p.

MARTINS, L. D. et al. Evidence of genetic tolerance to low availability of phosphorus in the soil among genotypes of Coffea canephora. Genetics and Molecular Research, 14:10576-10587, 2015.

MARTINS, L. D. et al. Genotypes of conilon coffee can be simultaneously clustered for efficiencies of absorption and utilization of N, P and K. African Journal of Agricultural Research, 11(38):3633-3642, 2016.

OLIOSI, G. et al. Seasonal variation in leaf nutrient concentration of conilon coffee genotypes. Journal of Plant Nutrition, 44(1):74-85, 2020.

PARTELLI, F. L. et al. Normas foliares e diagnóstico nutricional do cafeeiro conilon na pré-florada e granação, no Espírito Santo. Coffee Science, 11(4):544-554, 2016.

PEEL, M. C.; FINLAYSON, B. L.; MCMAHON T. A. Updated world map of the Köppen-Geiger climate classification. Hydrology Earth and System Sciences, 11(5):1633-1644, 2007.

R Development Core Team. The R Project for Statistical Computing. R Foundation for Statistical Computing, version 4.1.1(Kick Things). 2021. Available in: <https://www.rproject.org/>. Access in: October 27, 2021.

RAMALHO, J. C. et al. Cold impact and acclimation response of Coffea spp. plants. Theoretical and Experimental Plant Physiology, 26(1):5-18, 2014.

RAMALHO, J. C. et al. Cold-induced changes in mineral content in leaves of Coffea spp. Identification of descriptors for tolerance assessment. Biologia Plantarum, 57(3):495-506, 2013.

RIBEIRO, W. R. et al. Water deficit as a limiting factor to the initial growth of coffee conilon variety diamante. Journal of Experimental Agriculture International, 22(5):1-11, 2018.

RODRIGUES, W. N. et al. Genetic variability for sprout growth among genotypes of Coffea canephora led by bending of orthotropic stems. Genetics and Molecular Research, 16(4):gmr16039813, 2017.

SEVANTO, S. Phloem transport and drought. Journal of Experimental Botany, 65(7):1751-1759, 2014.

STARLING, L. C. T. et al. Variability and nutritional balance among genotypes of Coffea canephora (Rubiaceae) in drought versus adequate water supply. Genetics and Molecular Research, 17(4):1-13, 2018. 
TAIZ, L. et al. Fisiologia e desenvolvimento vegetais. 6.ed. Porto Alegre: Artmed, 2017. 888p.

TAQUES, R. C.; DADALTO, G. G. Agroclimatic zoning for conilon coffee culture in the state of Espírito Santo. In: FERRÃO, R. G. et al. Conilon coffee. 3.ed. Vitória: Incaper, p.70-83, 2019.

TULLY, K.; RYALS, R. Nutrient cycling in agroecosystems: Balancing food and environmental objectives. Agroecology and Sustainable Food Systems, 41(7):761-798, 2017.
VERDIN FILHO, A. C. et al. Conilon coffee yield using the programmed pruning cycle and different cultivation densities. Coffee Science, 9(4):489-494, 2014.

VICENTE, M. R. et al. Effect of irrigation on root development of coffee plants. Irriga, 24(2):378-391, 2019.

UNITED STATES DEPARTMENT OF AGRICULTURE - USDA. Soil taxonomy: A basic system of soil classification for making and interpreting soil surveys. Washington: USDA, 1999. 871p. 